\title{
The Success of Macroeconomic Policies of Selected Countries of North Africa
}

\author{
Ingrid Majerová
}

\begin{abstract}
The aim of the article was to analyze the success of economic policies of selected countries of North Africa - Egypt, Sudan and Morocco. The success was compared using the method of comparison in selected macroeconomic indicators such as gross domestic product growth rate, the share of current account deficit to gross domestic product, inflation rate and the unemployment rate from 2007 to 2012. For this comparison graphical form of magic quadrangle was chosen. From the resulting data magical quadrangle has shown that the most successful economic policy is implemented by Morocco, followed by Egypt and Sudan occupies last place.
\end{abstract}

Index Terms-Comparison, economic policy, magic quadrangle, North African countries.

\section{INTRODUCTION}

Africa as a whole is undoubtedly one of the most interesting parts of the world. However, the African continent can be divided into two distinct parts: the northern Saharan Africa and sub-Saharan part of Africa. As defined by the United Nations, within North Africa we rank the following economies: Egypt, Libya, Tunisia, Algeria, Morocco, Western Sahara and Sudan [1].

The territories of North Africa can be described as one of the most diverse parts of the continent. There has been a clash of cultures as well as many ethnic mixing religions. Each of the seven North African countries has a different economic status, which is determined by mineral resources, cultural monuments, and geographical lay-out of the country, religious affiliation of the population or ruling political system. These factors are closely related to implementation of various economic policies which is a tool for successful economic development of economies.

This article analyzes the implementation and success of economic policies in three selected countries of North Africa, namely Egypt, Morocco and Sudan. Economic policies in these countries are measured by four macroeconomic indicators - gross domestic product (GDP) growth, inflation rate, unemployment rate and the current account balance. The success of these policies is then displayed graphically using magic quadrangles, which are compared not only to the optimum, but also each other.

\section{Methodology}

To evaluate and compare the macroeconomic situation of a

Manuscript received September 5, 2013; revised November 6, 2013.

Ingrid Majerová is with the Department of Economics, Silesian University in Opava, School of Business Administration in Karviná, Univerzitní náměstí 1934, 73401 Karviná, Czech Republic (e-mail: majerova@opf.slu.cz). country a wide range of different variables and indicators might be used. The best predicative ability is attributed to four groups of indicators that measure the size of product, price level, unemployment and external economic position [2]. Another approach for measuring the macroeconomic performance is used in [3], [4].

Magical polygons are used as a standard tool for evaluation of success of economy and economic policy. Deviations from the optimum are represented using the four indicators of external and internal economic policies of the country. The optimum is defined by OECD and has the following amounts:

- GDP growth rate $-3 \%$,

- Unemployment rate $-5 \%$,

- Inflation rate $-2.5 \%$,

- Share of current account balance to GDP- $0 \%$.

\section{A. Calculation of Indicators of Economic Policy}

As it has already been mentioned, the aim of economic policy holders of each country is to achieve a satisfactory rate of growth of GDP, which is measured according to the following relation

$$
g=\left(Y_{t}-Y_{t-1} / Y_{t-1}\right) \times 100
$$

where

$Y_{t}$ is real GDP of current period and $Y_{t-1}$ is the real GDP of the previous period.

Another objective is the low unemployment rate, which is calculated from the relation

$$
u=U / U+L
$$

where $U$ is the number of the unemployed and $L$ the number of the employed. The sum of these two variables is economically active population.

For purpose of this comparison the inflation rate is calculated from the index CPI

$$
p=\left(C P I_{t}-C P I_{t-1} / C P I_{t-1}\right) \times 100
$$

where

$C P I_{t}$ is the price level in the period given, $C P I_{t-1}$ is the price level in the previous period.

The last variable that will be the subject of this analysis is the proportion of current account balance to GDP ratio, which is an indicator of external stability of the country and its value is derived from the relation

$$
b=\left(C A_{B P} / Y_{t}\right) \times 100
$$

where 
$C A_{B P}$ expresses the current account balance for the period and $Y_{t}$ nominal GDP.

\section{B. Construction of Magical Quadrangle}

Generally, the economic productivity of a country depends on the initial economic conditions and practical economic policy of the government, which usually pursues several objectives simultaneously [5]. To achieve mutual harmony of these objectives in economic terms is very difficult. Magic quadrangle conflict was characterized by individual goals. If the government of a country intended to increase economic growth, in the same time it decreases the unemployment rate, which means that these two indicators are complementary. On the other hand, there are contradictory objectives, conflict goals, the example of which is economic growth that is associated with the growth of the inflation rate of the country. A compromise solution in this situation is magical quadrangle, which is shown in Fig. 1.

When constructing the quadrangle, some adjustments have to be done, because the Excel program, in which the quadrangle was designed, records the value of unemployment rate and inflation rate in the opposite order. This is due to the fact that the centre of the graph indicates the initial value of zero for all the parameters. The inflation rate and the unemployment rate in the traditional approach to magical quadrangle records the value of zero at the end of the axis toward the centre of the graph.

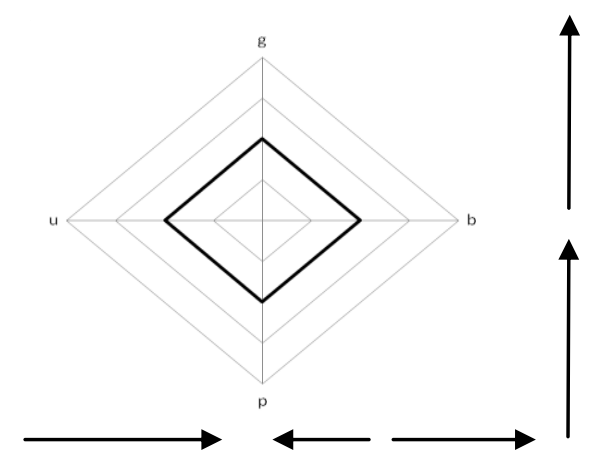

Fig. 1. Optimal magic quadrangle.

Table I shows the values located on the axes of magical quadrangle and a conflict in achieving individual goals. The rule applies that the larger area of quadrangle is, or even farther from the center are the measured values, the success of economic policy is higher.

TABLE I: INDICATORS OF SUCCESSFUL ECONOMIC POLICY

\begin{tabular}{lll}
\hline \hline Indicator & abbrev. & goal \\
\hline GDP growth rate & $\mathrm{g}$ & maximum \\
Inflation rate & $\mathrm{p}$ & minimum \\
Unemployment rate & $\mathrm{u}$ & minimum \\
Share of CA balance to GDP & $\mathrm{b}$ & zero \\
\hline \hline
\end{tabular}

\section{Evaluation of The SuCCESS OF ECONOMiC POLICIES AND THEIR COMPARISON}

Before the magic quadrangle of economies to their mutual comparison will be created, we analyze the situation of the above mentioned four variables in individual economies. The data used in this analysis were drawn from databases of World Bank [6]-[11] and Trading Economics [12]-[14].

\section{A. Macroeconomic Indicators of the Countries of North Africa \\ 1) Egypt}

The positive results of Egyptian economy, which started with reform efforts in 2004, were interrupted due to the so-called Arab Spring in 2011, and currently the Egyptian economy continues to deal with problems.

The GDP growth rate has been increasing since 2004. The significant increase was recorded in 2008 , by $7.2 \%$. Due to this increase, the Egyptian economy managed to maintain a relatively high growth economy during three years in a row (2006 - 2008). By 2011, the Egyptian economy grew by an average of $5 \%$ per quarter, then there was a big drop and for the economy it is difficult to return to its original values.

The unemployment rate in Egypt has a growing trend. By the year 2010 it was below ten percent, but in recent years it has increased in almost $3.5 \%$ compared to 2009 , due to revolutionary changes [15]. The most significant inflationary item is currently the price of food. The index of consumer prices significantly increased in Egypt, due to low revenues in Russia, China, Canada and Australia [16].

Even though the value of GDP reported a non-negative trend, the share of current account deficit to GDP decreased significantly. The highest decrease was observed during 2008-2010, a period when the countries were afflicted by the food crisis and the wave of riots.

The development of macroeconomic indicators of Egypt is shown in Table II.

TABLE II: DEVELOPMENT OF MACROECONOMIC INDICATORS OF EGYPT IN

\begin{tabular}{lcccccc}
\multicolumn{7}{c}{ YEARS 2007-2012 } \\
\hline \hline Indicator & 2007 & 2008 & 2009 & 2010 & 2011 & 2012 \\
\hline $\mathrm{g}$ & 7.1 & 7.2 & 4.7 & 5.1 & 1.8 & 2.2 \\
$\mathrm{u}$ & 8.9 & 8.7 & 9.4 & 9.0 & 11.2 & 12.5 \\
$\mathrm{p}$ & 9.3 & 18.3 & 11.8 & 11.3 & 10.1 & 7.2 \\
$\mathrm{~b}$ & 0.3 & -0.9 & -1.8 & -2.1 & -2.4 & -3.2 \\
\hline \hline
\end{tabular}

\section{2) Morocco}

The economy of Morocco is based on the model of an open economy. The country performs extensive investments and structural reforms and economic sectors, especially the tertiary service sector, are modernized.

As a result of political reforms in 1990's, Moroccan economy reached satisfactory macroeconomic results in 2000 - the unemployment and inflation remain at the lowest level compared to Egypt and Sudan, the growth rate of gross domestic product is slower, but does not record any significant declines [17]. The Moroccan government is trying to bring in enough capital; one of the strategic tools is travelling and tourism.

In the field of unemployment, the major problem is the high percentage of young unemployed people (18.6\%) who are forced to work in other countries, and the government is unable to create enough jobs and thus to absorb labor force in the country.

The balance of payments of the country includes all major 
economic indicators - increasing demand of local population and reducing demand of foreign investors. Deficit in the current account has significantly enhanced since 2007 (except in 2010), despite the long-term positive results in the balance of services, current transfers, increasing agriculture and mining. One of the reasons of this development is the weakening of foreign direct investments in 2009-2011.

The development of macroeconomic indicators of Morocco is shown in Table III.

TABLE III: DEVELOPMENT OF MACROECONOMIC INDICATORS OF MOROCCO IN YEARS 2007-2012

\begin{tabular}{lcccccc}
\hline \hline Indicator & 2007 & 2008 & 2009 & 2010 & 2011 & 2012 \\
\hline $\mathrm{g}$ & 2.7 & 5.6 & 4.8 & 3.7 & 4.5 & 2.7 \\
$\mathrm{u}$ & 9.7 & 9.6 & 9.1 & 9.1 & 8.9 & 9.0 \\
$\mathrm{p}$ & 2.0 & 3.7 & 1.0 & 1.0 & 0.9 & 1.6 \\
$\mathrm{~b}$ & -0.2 & -5.1 & -5.5 & -4.3 & -8.0 & -7.9 \\
\hline \hline
\end{tabular}

\section{3) Sudan}

The economy of Sudan has shown typical characteristics of developing economies during the monitored years - high GDP growth, high unemployment and inflation rate, the deficit of the current account balance (more about development in Least Developed Countries, which include Sudan see [18]). The situation continued to deteriorate even after the country was divided into two separate political units - Sudan and South Sudan and the prediction of future development (of both economies) is not favorable.

From 2007 to 2010 Sudan reached a satisfactory rate of GDP growth, in 2011, there was a decline in GDP growth as a result of dividing of the country into Sudan and South Sudan, where all oil fields are located. In the field of industrial production, the priority was to provide sufficient volume of investments in the mining industry, in order to compensate the losses of oil revenue.

Sudanese labor market is underdeveloped and heavily dependent on agriculture and informal sector. The unemployment rate has traditionally been well above ten percent limit. The situation improved in 2011 and 2012, when the unemployment rate fell by about $1.7 \%$, respectively $1.2 \%$. The major problem is high youth unemployment [19] similarly as in the countries of the European Union [20]. The programs to promote youth employment in the country are coordinated by national strategy for growth and employment, but these efforts do not lead to significant results. Most of the population lives on the border of absolute poverty on less than one dollar a day.

Similarly to Egypt, the neighboring Sudan was affected by the food crisis in 2008 and 2009, which hit North Africa and caused the increase in food prices and other commodities. In comparison to 2007 and 2012, the difference in the measured values of the inflation rate was $15.4 \%$. The significant increase was seen in 2008 with the difference of $6.3 \%$ compared to the previous year.

Due to division of Sudan, a significant decline in the share of current account deficit to GDP was caused, which was shown with a delay in 2012. Owing to this move, Sudan has lost $75 \%$ of revenues from oil exports, which caused a noticeable weakening of the economy.
The development of macroeconomic indicators of Sudan is shown in Table IV.

TABLE IV: DEVELOPMENT OF MACROECONOMIC INDICATORS OF SUDAN IN

\begin{tabular}{lrrrrrr}
\multicolumn{7}{c}{ YEARS 2007-2012 } \\
\hline \hline Indicator & 2007 & 2008 & 2009 & 2010 & 2011 & 2012 \\
\hline $\mathrm{g}$ & 10.2 & 6.8 & 6.0 & 5.1 & 4.7 & 2.0 \\
$\mathrm{u}$ & 16.8 & 16.0 & 14.9 & 13.7 & 12.0 & 10.8 \\
$\mathrm{p}$ & 8.0 & 14.3 & 11.2 & 13.0 & 18.0 & 23.4 \\
$\mathrm{~b}$ & -5.8 & -4.2 & -7.3 & -1.0 & -1.1 & -7.8 \\
\hline \hline
\end{tabular}

\section{B. Comparison of the Success of the Economies}

To establish quadrangle itself, it was necessary to create averages of macroeconomic variables of each country in the period 2007-2012. Table V shows average values of the indicators for the purpose of constructing a magic quadrangle of selected countries.

TABLE V: SUCCESS OF ECONOMIC POLICY OF COMPARED COUNTRIES

\begin{tabular}{llrrrr}
\hline \hline Country & marking & $\mathrm{g}$ & $\mathrm{p}$ & $\mathrm{u}$ & $\mathrm{b}$ \\
\hline Egypt & $\ldots \ldots \ldots .$. & 4.76 & 11.33 & 9.95 & -1.68 \\
Morocco & - & $-\ldots 0$ & 1.70 & 9.23 & -5.15 \\
Sudan & --- & 5.80 & 14.65 & 14.03 & -4.15 \\
Optimum & & 3.00 & 2.50 & 5.00 & 0.00 \\
\hline \hline
\end{tabular}

Fig. 2 shows a comparison of Egypt, Morocco and Sudan compared with the optimal values of the magic quadrangle based on the data in Table $\mathrm{V}$.

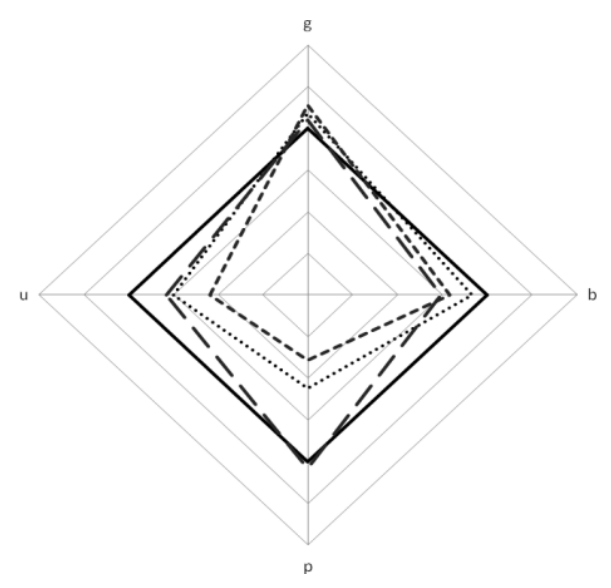

Fig. 2. Magic quadrangle of the compared economies.

The economy of Morocco appears as the most favorable in comparison of individual indicators. The vertical axis of the angle, divided into GDP growth and inflation, exceeded the optimum value of the magical quadrangle, but the horizontal axis at the level of unemployment rate and the ratio of current account deficit to GDP shows a significant deficit of about four per cent on both sides. In comparison to the Egyptian economy, which is ranked as the second, Morocco is more efficient in the summary of unemployment rate and the inflation rate, while the compared values of the ratio of the current account deficit and the growth rates are lower. The highest difference of values of two economies is reported in the inflation rate, with the difference of $10.33 \%$ in favor of Morocco, resulting in significantly deformed shape of Egyptian quadrangle.

Egyptian quadrangle achieved the highest value in the 
balance of payments with the deviation from the optimum $-1.68 \%$, the growth rate of GDP in the aggregate exceeded both the optimum and Morocco as well. Regarding the unemployment rate, the value of Morocco and Egypt differed by only $0.72 \%$, which is a negligible value within five years. As it has been mentioned above, the strong deformation caused the inflation rate. If the value of inflation rate was at least at the optimum, the Egyptian economy would be considered as the most successful.

The last to be mentioned is Sudan. In contrary to expectations, the GDP growth rates were at the highest level with the difference from the optimum of about $2.8 \%$. At the ratio of current account deficit of Sudanese economy surpassed Morocco, at the same time, however, did not even reach the optimum of neither the values nor the values of Egyptian economy. As regards the remaining indicators, the decline of values with a few percent differences is evident. Sudan inflation rate was in almost thirteen percent deficit compared to Morocco, compared to Egypt it was in about three percent deficit.

TABLE VI: RANKING OF ECONOMIC SUCCESS

\begin{tabular}{llllll}
\multicolumn{5}{c}{ TABLE VI: RANKING OF ECONOMIC SUCCESS } \\
\hline \hline Country & $\mathrm{g}$ & $\mathrm{p}$ & $\mathrm{u}$ & $\mathrm{b}$ & Rank \\
\hline Egypt & 2 & 1 & 2 & 2 & 1 \\
Morocco & 3 & 3 & 1 & 1 & 2 \\
Sudan & 1 & 2 & 3 & 3 & 3 \\
\hline \hline
\end{tabular}

If we compare the individual economies according to various indicators of internal and external equilibrium, the economy of Egypt would be the leader. The difference lies in the indicator of inflation, which according to Table VI ranked Egypt at the second place, the difference compared to Morocco was $9.33 \%$.

The highest value of the growth rate of GDP had Sudan, followed by Egypt and Morocco. The indicator of ratio of current account deficit to GDP was "dominated" by Egypt, followed by Sudan and the third place belonged to Moroccan economy. The difference between the first and the third place is only $3.47 \%$, which is a small area in the graphical expression. For the remaining indicators the best results were reached only by Moroccan economy, followed by Egypt and Sudan. The difference in the first and the third place by the inflation rate reaches $12.95 \%$, by the unemployment rate $4.8 \%$.

\section{CONCLUSION}

The aim of this article was to carry out economic comparison of the North African countries, for the comparison of which economies of Egypt, Sudan and Morocco were selected. The countries were compared using the comparative method in the form of magical quadrangle, to which the values of the growth rate of GDP, the ratio of current account deficit to GDP, inflation and unemployment are applied on each half-axis angle.

The resulting data of magical quadrangle showed that the most advanced economy is Morocco, followed by Egypt and Sudan took last place. Comparing the indicators, the economies, however, have reached different results. The first place belonged to Egypt, followed by Morocco and the position of Sudan was unchanged. The difference in the outlined methods results from the inclusion of the size and shape of quadrangle area that gives evidence of a successful economic policy as a whole.

The development of macroeconomic indicators in the period 2007-2012 was influenced by many factors; the most significant was the third oil shock in 2008, the food crisis, the revolution in 2011 and the subsequent political situation after 2011. All of these events significantly influenced individual economies and affected economic indicators in a negative way. The return to the original values of the period compared is expected in 2016.

\section{REFERENCES}

[1] Geographical Region and Composition. United Nations. [Online]. Available:

http://millenniumindicatorsun.org/unsd/methods/m49/m49regin.htm\#a frica

[2] A. Soukup, S. Burian, K. Sluková, and L. Severová, Mezinárodní Ekonomie - Cvičebnice, 1st ed. Praha, Czech Republic: CZU, 2011.

[3] M. Tvrdon. "A non-parametric approach to some marcoeconomic indicators: Evidence from te European Union," in Proc. 19th International Business Information Management Association Conference, Norristown, 2012, pp. 677-684.

[4] S. Chudarkova and T. Verner "Relation between human capital and economic growth: The case of Austria," in Proc. 30th International Conference on Mathematical Methods in Economics. Karviná, 2012, pp. 344-349.

[5] P. Tuleja, Komparace Ekonomické úRovně Vybraných Zemí Střední a Východní Evropy a Vybraných zemÍ Evropské Unie v Letech 1993 2001. Karviná, Czech Republic: SU OPF, 2002.

[6] World Development Indicators 2013, World Bank, Washington DC, 2013.

[7] World Development Indicators 2012, World Bank, Washington DC, 2012.

[8] World Development Indicators 2011, World Bank, Washington DC, 2011.

[9] World Development Indicators 2010, World Bank, Washington DC, 2010.

[10] World Development Indicators 2009, World Bank, Washington DC, 2009.

[11] World Development Indicators 2008, World Bank, Washington DC, 2008.

[12] Egypt Inflation Rate. Trading Economics. [Online]. Available: http://www.tradingeconomics.com/egypt/inflation-cpiEconomics

[13] Sudan Inflation Rate. Trading Economics. [Online]. Available: http://www.tradingeconomics.com /sudan/inflation-cpi

[14] Morocco Inflation Rate. Trading Economics. [Online]. Available: http://www.tradingeconomics.com/morocco/inflation-cpi

[15] K. Knipp. (May 2013). Egypt gripped by unemployment. Deutsche Welle. [Online]. Available: http://www.dw.de/egypt-gripped-by-unemployment/a-16825597

[16] M. Moustafa. (April 2013). Final Issue: Problem of unemployment likely to worsen in Egypt. Egypt Independent. [Online]. Available: http://www.egyptindipendent.com/news/final-issue-problem-unemplo yment-likely-worsen-egypt

[17] D. Furceri, S. Mazraani, and B. Versailles, Morocco: Selected issues Working paper IMF country report No. 13/110, International Monetary Fund, May 2013.

[18] I. Majerova, "Global financial crisis and its impact on the least developed countries," in Proc. 13th International Conference of Finance and Banking. Karviná, 2012, pp. 216-228.

[19] A. R. Mahdi, "Youth and emloyment in Sudan," Working Paper Sudanese Development Initiavite, United Nations Developed Programme, August 2011.

[20] K. Gajdova and G. Cieslarova, "Changes in selected characteristics of the EU labour market in times of economic crisis," in Proc. 19th International Business Information Mnagement Association Conference. Norristown, 2012, pp. 628-635. 


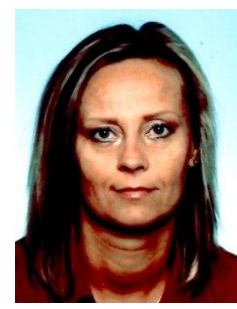

Ingrid Majerová was born in Karviná, Czech Republic, 9th May 1971. She graduated her master studies at the Faculty of Economics, VSB-Technical University of Ostrava, Czech Republic in the field of national economy in 1994. In 1998 she received a doctoral degree therein, in the field of economics. She worked in the private sector as an economist and head of management from 1997 to 2002. In 2004 she began working as an assistant professor at the Silesian University, Faculty of Business Administration, Czech Republic, where at the Department of Economics she works to this day. Her most important publications include: "Leas Developed Countries in Indexes of Human Development and Poverty," in Proc. of the 18th IBIMA Conference Innovation and Sustainable Economic Competitive Advantage: From Regional Development to World Economies.
Norristown, 2012, pp. 1210-1224, "International Development Cooperation of the Czech Republic in the Context of European Development," Prague Economic Papers, vol. 2. pp. 166-185, June 2012, "International Development Cooperation of the Czech Republic: a Comparison with new EU-Donors," in Tvrdon, M. and I. Majerova (eds.), Proc. of the 10th International Conference Economic Policy in the European Union Member Countries, Karviná, 2013, pp. 208-218. She specializes in the area of international economics, problems of developing countries and international development assistance.

Dr. Majerová was a member of the organizing and program committees of several international conferences such as the International Scientific Conferences Economic Policy in the European Union in the years 2009-2013, International Scientific Conference IBIMA 2013 in Vienna and was co- editor of a major Proceedings of International Scientific Conference Economic Policy in the European Union 2012. 